\title{
The Importance of Teaching Pragmatics in the Classrooms (Focus on Complimenting)
}

\author{
Saeedeh Shokouhi \& Amir Rezaei \\ Department of Language Teaching, Zanjan Branch, Islamic Azad Universiy, Zanjan, Iran \\ Tel: 98-912-744-7013Ｅ-mail: Shokouhi.Saeede@gmail.com
}

Received: May 2, 2015 Accepted: June 22, 2015 Published: June 24, 2015

doi:10.5296/jsel.v3i1.7890 URL: http://dx.doi.org/10.5296/jsel.v3i1.7890

\begin{abstract}
This review explores the importance of teaching pragmatics in the classrooms. Developing pragmatic competence needs experience, knowledge and language awareness. According to Fasold (2006) pragmatics involves using language in particular situations. In this review the speech act of complimenting is selected as the focus of teaching. People compliment each other to maintain or create a special relationship to improve their actions. The early studies by Manes and Wolfson (1981) report the formulaicity of compliments in American English. Finally, this review shows that teachers should pay more attention to pragmatics and teaching it in the classroom. Lack of pragmatic knowledge may cause a failure in communication. Besides emphasizing on only grammar aspects teachers should teach the appropriate usage of language in different situations.
\end{abstract}

Keywords: pragmatics, teaching pragmatics, complimenting 


\section{Introduction}

Interlanguage pragmatics is the study of the learners use and acquisition of linguistic patterns in a second language (Bardovi-Harlig, 1996; Kasper, 1999; Rose, 2000). Pragmatics is a sub field of linguistics that has been defined as: "the study of language from the point of view of users. Especially of the choices they make, the constraints they encounter in using language in social language and the effect of their use of language has on other participants in the act of communication"(Crystal, 1997).

\subsection{Definition of Pragmatics}

Pragmatics focuses on the use of language in particular situations; it explains the elements that influence on both literal and nonliteral meaning in peoples' communication. According to Fasold (2006) "Pragmatics concerns both the relationship between context of use and sentence meaning, and the relationships among sentence meaning, context of use, and speaker's meaning (p.137).”

In Kasper's (1997 a) words, pragmalinguistics "includes strategies like directness and indirectness, routines, and a large range of linguistic forms which can identify or soften communicative acts (p.1)".for Kasper and Rose (2002), pragmalinguistic knowledge needs mapping of form, meaning, force, and context.

The benefit of studying language through pragmatics is that the people can express the other's meaning and the important disadvantage is that analyzing the peoples' concepts is hard objectively. This pragmatics is interesting because it's about how people make sense of each other linguistically, but it can be a disappointed area of study because it needs us to make sense of people and what they have in mind (Yule, 1996.p.3).

\section{The Importance of Pragmatics}

As Locastro (2012) mentioned improving the learners' pragmatic knowledge is as important as developing one's IT and technology skills. Both are important for the world of today. ESL/EFL teachers are on the frontlines of pragmatic development. They also had great responsibility for learners who intend to use the L2 for study or work abroad. So the teachers in particular need to pursue their own ability to think critically about language data and instances of use to prepare themselves. Their learners benefit from the explicit teaching of pragmatics by their teachers and ideally become autonomous learners, doing pragmatics to solve communication problems and pushing their competence level (p.308).

According to Yined Tello Rueda (2006) pragmatic studies should consider to provide the students with linguistic tools and helping them to learn and understand the action in an appropriate way.( This may be concerned with teaching TL culture considering as process. This perspective of culture is shared by several authors, such as Byram and Morgan (1994) Cortazzi and Jin (1999), Fantini (1997), and Kramsch (1998), who identify that language expresses, embodies, and symbolizes cultural reality (p.308). 


\section{The Importance of Teaching Pragmatics}

The major problem in teaching pragmatics is the sheer number of speech acts, as Williams (1988) investigates. He explains that the large number of language functions and speech acts makes the teaching of a particular speech act an unattainable goal and instead suggests that 'the focus should ... be ... on using language in ongoing discourse, As Bardovi - Harlig (1991) mentions the real responsibility of the classroom teacher is making students more aware about existing pragmatic functions in language, especially in discourse. The teachers should know about these speech acts and their elements to use the natural input for the students in a particular content, for a particular purpose, and as part of a strategy' (1988: 46).

According to Brock (2005, p.20) for classroom instruction to pragmatic competence the teachers should consider the simple acronym S.U.R.E.to guide them as they help their students See, Use, Review, and Experience pragmatics in the EFL classroom.

See

Teachers can help their students see the language in context,

raise consciousness of the role of pragmatics, and explain the

function pragmatics in specific communicative events.

Use

Teachers can develop activities through which students use

in contexts ( simulated and real) where they choose how they

interact based on their understanding of the situation suggested

by the activity.

\section{Review}

Teachers should review, reinforce, and recycle the areas of pragmatic competence previously taught.

\section{Experience}

Teachers can arrange for their students to experience and

observe the role of pragmatics in communication.(p.20)

Intercultural miscommunication is often caused when learners fall back on their L1 sociocultural norms in realizing speech acts in target language. This is referred to as pragmatic transfer. Rizk (2003) defines pragmatic transfer as "the influence of learners' pragmatic knowledge of language and culture other than the target language on their comprehension, production and acquisition of L2 pragmatic information" (p.404). 


\section{Complimenting}

Research on compliments is traced back to the work of Nessa Wolfson and Joan Mane(Manes\&Wolfson,1981;Wolfson,1981a,1981b,1983,1984,1988,1989;Wolfson\&Manes,1 980;Manes,1983), which provided the first comprehensive description of the formulaicity of compliments in American English . They found that a range of syntactic formula as Manes and Wolfson (1981) report falling into one of the nine syntactic formula. The nine syntactic formulas described $\mathrm{M} \& \mathrm{~W}$ provide a useful overview of pragmalinguistic resources available for complimenting in English.

\subsection{Definition of Complimenting and its Importance}

A compliment is a speech act which explicitly or implicitly attributes credit to someone other than the speaker, usually the person addressed, for some 'good' (possession, characteristic, skill, etc.) which is positively valued by the speaker and the hearer.(Holmes, 1986:485).The compliment speech event has been a subject of careful sociolinguistic research in recent years. In an early study, Manes and Wolfson (1981) investigating compliment utterances in American English, found that there are a large number of patterns at syntactic and semantic levels. According to their finding $85 \%$ of the compliments consisted of three core syntactic patterns. These were:

(i)NP is /looks (really) ADJ

(ii)I (really) like/love NP

(iii)DET/PRON is (really) (a/an) ADJ NP (e.g., "That shirt is so nice")

(e.g., "I love your hair")

(e.g., "This is really a great meal")

(Manes and Wolfson, 1981. P.116-132)

They also found that two-thirds of the adjectives that complimenters used were nice, pretty, beautiful and great. Two verbs like and love used for 86 percent of the positive verbs. They identified that compliments are formulaic in syntactic and in the lexical items,addressed, for some 'good' (possession, characteristic, skill, etc.) which is positively valued by the speaker and the hearer(Holmes, 1986:485).

\subsubsection{Functions of Complimenting}

There are many functions of complimenting. People compliment each other to maintain or re-establish a social relationship, to improve a desired action (e.g., teacher-student interaction), or to soften a speaker's discourse before uttering a face threating act (Holmes, 1986; Brown and Levinson, 1987).Holmes (1988:464) stated that compliments are functionally complex speech acts which served as "solidarity signals, commenting on friendship, attenuating demands, smoothing ruffled feathers and bridging gaps created by possible offenses". Compliments are positively affective speech acts that increase the solidarity between individuals. Compliments have been said to "grease the social wheels" and 
serve as "social lubricants" that create or maintain rapport (wolfson 1983:89).

Another function of compliments, in addition to affective function is that it is possible that some compliments have a stronger referential message than others. Johnoson and Roen (1992) found that compliments conveyed both affective (or interpersonal) meaning and referential (or ideational) meaning. In some environments compliments function as praise and encouragements. So, the relationship between people is important in interpreting the functions of a compliment.

\section{Conclusion}

The teachers should improve the learners' understanding of the frames of the interaction and rules of politeness within the target culture. It is also the teachers' responsibility of providing learners with the necessary tools of appropriate pragmalinguistic and sociopragmatic decisions in the target language. According to Hymes (1972 cited in Kramsch 1993:34), "The key to understanding language in context is to start not with language, but with context".

Lack of pragmatic knowledge might cause the leaners to be unsuccessful in their communication and, thus, may result in breakdown in the interpersonal relationship between the speakers and listeners. According to Byram (1997), to successfully master English language in international communication, the people need to have intercultural communicative competence in addition to communicative competence as a successful non-native speaker. Besides emphasizing on only grammar aspects, teachers must encourage language learners to pay more attention to how to use language appropriately in different contexts and avoid making pragmatic mistakes to breakdown the communication. To help learners avoid making pragmatic mistake, it is necessary to teach them the sociocultural rules of the English. Pragmatic knowledge of a language is better acquired by exposing the learners to natural environment and authentic materials. In the case of EFL, students are deprived of such conditions; moreover, these conditions cannot be completely provided for in the classrooms, so students may need special training in this aspect. Foreign language learners should be taught to recognize the situations and circumstances in which different kinds of language are appropriate, and should be given enough practice in using the proper linguistic forms according to those contexts.

\section{References}

Bardovi-Harlig, K. (1996).Pragmatics and language teaching. Bringing pragmatics and pedagogy together. Pragmatics and Language Learning, 7, 21-39.

Bardovi-Harlig, K., Hartford, B. A. S., Mahan-Taylor, R., Morgan, M. J., \& Reynolds, D. W. (1991). Developing pragmatic awareness: Closing the conversation. ELT Journal, 45(1), 4-15.

Bialystok, E. (1993). Symbolic representation and additional control in pragmatic. Interlanguage pragmatics. (pp. 43-57). Oxford: Oxford University Press.

Brock, M. N. (2005). Teaching Pragmatics in the EFL Classroom? Sure You Can!. TESL Reporter, 38(1), 17-26. 
Brown, P., \& Levinson, S. C. (1987). Politeness: Some universals in language use.

Byram, M. (1997). Teaching and assessing intercultural communicative competence.Clevedon:Multilingual Matters.

Byram, M., \& Morgan, C. (1994).Teaching and learning language and culture. Clevedon, UK: Multilingual matters.

Cam Barron, A. (2003). Acquisition in interlanguage pragmatics: How to do things with words. In S. Blum-Kulka, \& G. Kasper (Eds.), Interlanguage pragmatics.

Cortazzi, M., \& Jin, L. (1999). Cultural mirrors; material and methods in the EFL classroom. In Hinkel, E. (Ed.) Culture in second language teaching and learning (pp.196-220). Cambridge: Cambridge University Press.

Crystal, D. (1997). A dictionary of linguistics and phonetics (4th ed.). Cambridge, MA: Blackwell.

Fantini, A. (1997). New ways of teaching culture. Washington,DC: TESOL. Quarterly, 20, 689-699.

Fasold, R. (2006). An Introduction to Language and linguistic. Cambridge university press.

Felix, S. (1981). On the (in) applicability of Piagetian thought to language learning. Studies in Second Language Acquisition, 3(2), 201-220.

Holmes, J. (1986).Compliments and compliment responses in New Zealand English. Anthropological Linguistics, 28(4), 485-508.

Holmes, J. (1988). Paying compliments: A sex -preferential politeness strategy. Journal of Pragmatics, 12, 445-465.

Hymes, D., (1972). Foundations in sociolinguistics. Philadelphia: university of Pennsylvania Press.in a study abroad context. Amsterdam/Philadelphia: Benjamins.bridge: Cambridge University Press.

Johnson, D. M., \& Roen, D. H. (1992). Complimenting and involvement in peer - reviews: Gender Variation Language in Society, 21-27, 57.

Kasper, G. (1997). Can pragmatic competence be taught? Second language Teaching \& Curriculum center (Online).

Kasper, G., \& Rose, K. (1999). Pragmatics in SLA. Annual review of applied linguistics, 19, 81-104.

Kramsch, C. (1998). Language and Culture. Oxford: Oxford University Press.

Liu, J. (1997). Assessing EFL learners' interlanguage pragmatic Knowledge: Implications for testers and teachers. Reflections on English Language Teaching, 5(1), pp. 1-22.

LoCastro, V. (2012). Defining the terriotery. In V. LoCastro , Pragmatics for language educators: A Sociolinuistic Perspective. pp.3-17. London: Routledge. 
Manes, J. (1983). Compliments: A mirror of cultural values. In N. Wolfson \& E. Judd (Eds.). Socioliguistic and Language Acquisition (pp. 82-95). Rowley, MA: Newbury House.

Manes, J., Wolfson, N. (1981). The compliment formula. In Coulmas, F. (Ed.), Conversational Routine:Explorations in Standardized Communication Situations and Prepatterned Speech. Mouton, TheHague, pp. 115-132.

Rizk, S. (2003). Why say "NO!" when you refuse? TESOL Arabia 2002 Conference Proceedings, 7, 401- 431.

Rose, K. R. (2000). An exploratory cross-sectional study of interlanguage pragmatic development. Studies in Second language Acquisition, 22, 27-67.

Rose, K. R., \& Kasper, G. (2002). Pragmatic Development in a second language. Blackwell publishing.

Rose, K.R..(1999). Teachers and students learning about requests in Hong Kong. In: Hinkel, E. (Ed.), Culture in Second Language Teaching and Learning. Cambridge University Press, Cambridge, pp. 167-180.

Wolfson, N. (1981). Compliments in cross-cultural perspectives. TESOL Quarterly, 15(2), 117-124.

Wolfson, N. (1988). 'Native and nonnative variation in complimenting behavior' .Paper presented at the Conference on Pragmatics and Language Learning, Urbana.IL.

Wolfson, N., \& Manes, J. (1980). The compliment as a social strategy. Papers in Linguistics: International Journal of Human Communication, 13(3), 391-410.

Yule, G. (1996). Pragmatics, New York: Oxford University Press.

\section{Copyright Disclaimer}

Copyright for this article is retained by the author(s), with first publication rights granted to the journal.

This is an open-access article distributed under the terms and conditions of the Creative Commons Attribution license (http://creativecommons.org/licenses/by/3.0/). 